Vol. 7, No. 1, 2021

Oleh Borshovskyi ${ }^{1}$, Halyna Koznarska ${ }^{2}$, Halyna Lukashchuk ${ }^{3}$

\title{
ORGANIZATION OF THE URBAN PUBLIC PARK OF CULTURE AND RECREATION IN THE CITY OF UZHHOROD
}

\author{
${ }^{1}$ Postgraduate Student, Department of Urban Planning and Design \\ Lviv Polytechnic National University, Lviv \\ e-mail: oleh.i.borshovskyi@lpnu.ua \\ orcid: 0000-0002-5269-1670 \\ ${ }^{2}$ Associate Professor, Department of Urban Planning and Design \\ Lviv Polytechnic National University, Lviv \\ e-mail: halyna.y.koznarska@lpnu.ua \\ orcid: 0000-0002-1705-7463 \\ ${ }^{3}$ Associate Professor, Department of Urban Planning and Design \\ Lviv Polytechnic National University, Lviv \\ e-mail: halyna.b.lukashchuk@lpnu.ua \\ orcid: 0000-0003-4043-8771
}

Received: 25.01.2021 / Revised: 17.04.2021 / Accepted: 18.04.2021

(C) Borshovskyi O., Koznarska H., Lukashchuk H., 2021

https://doi.org/10.23939/as2021.01.001

Astract. The parks of Uzhhorod have been studied, the culture and recreation park relocation expediency from Pidzamkovyi to Bozdoskyi has been proved. The Pidzamkovyi park, with an area of only 4 hectares, has not withstood the load placed on it for a long time and does not meet the requirements of the Building code for such facilities. Further use of this park for cultural events will lead to the loss of valuable plantations and the destruction of the historic landscape of the city. Therefore, the issue of removing the functions of the culture and recreation park from it is now extremely acute. Instead, this area can be used as a place for local recreation of the surrounding residents. Bozdosky Park, which contains all the necessary components for the organization of leisure activities of the city population: accessibility, sufficient space and recreational resources is offered as the alternative for the function of an urban public park of culture and recreation.

Key words: culture park, recreation, landscape and recreation area, monument of garden and park art.

\section{Problem statement}

Parks play a key role in forming a landscape-recreational zone of the city. They create aesthetic attractivity, regulate temperature and clean the air, positively influence the psychological state of a person. Parks attract most of all the inhabitants during their leisure time, that is why it is important to define their functional purpose for the organization of landscaped territories that consist of green plantations of general use, green plantations of limited use and special assignment (DBN B.2.2-12:2018).

General city park of culture and rest is the centre of recreation where the main culture-mass events connected with leisure take place. Its planning organization should provide the combination of the main functional zones that will allow having rest for various categories of the city inhabitants. The location of 
such a park should blend into the planning structure of the city to provide comfortable accessibility. The evident advantage is the existence of inhabitants of those residential areas that are located within pedestrian accessibility to the park. However, we should remember about the distant city districts which should also be provided with access to the general city centre for rest and leisure. For achieving this it is necessary not only to connect the main functional park connections with the stops of public transport but also to organize the places for private cars parking. For organizing such a type of park it is necessary to allocate a considerable area within the city limits, that is why the minimal area of the general city park of culture and rest should constitute 15-20 hectares (Mistobudivne proektuvannia, 2016).

In the historically formed cities often parks, which perform the function of the general city park of culture and rest, do not correspond to the main demands concerning the organization. A similar situation is in the city of Uzhhorod, where the role of the general city recreation centre is played by the park Pidzamkovyi.

\section{Analysis of recent research and publications}

Green plantations are a natural element that provides a comfortable environment for living for a person. The geographical position and the warm, humid climate of the Mid-Danube lowland contributed to the spreading of various types of trees in Uzhhorod (Soima, A. D., 2011).

For the first time about the landscape gardening of Uzhhorod, it was mentioned in the XVII century. The history of the city's landscape gardening was described by the well-known botanist S. Fodor (1957). In his work on the city's landscape gardening, the author defines four historical periods.

To the first one, S.Fodor dates the period of the feudal formation, during which, starting with the XVII century and up to the year 1848 the first measures on landscape gardening were taking place. There took place the first artificial forest plantings in the valley of the Uzh river, around the Uzhhorod castle. These forests were the hunting grounds for the feudal. A small part of these plantations has been left until now in Pidzamkovyi park.

To the second period belong the plantings of the trees from 1848 to 1914 . On the created by the feudal small holdings, there was taking place successful acclimatization of the South-European, Asian and American types.

The third period started in 1919 when the Transcarpathian region entered the Czecho-Slovak republic and lasted until 1944. During this period the main attention is paid to the landscaping of streets and the reconstruction of the earlier laid parks, public gardens, and green areas. There is a system of green plantations near newly-built quarters. To these plantations belong many exotic and decorative forms of autochthonous species.

The fourth period is landscape gardening in the Soviet period (Fodor S. S. 1951; Fodor S. S., 1957).

Nowadays, Uzhhorod is one of the greenest oblast centres. The researchers pay much attention to the study of the city environment of embankments, defining the factors of forming the landscape-architectural organization of the embankments (But N. K., 2013).

\section{Objective of the article}

The parks of Uzhhorod have been researched, the expediency of relocating the park of culture and recreation from Pidzamkovyi to Bozdoskyi park has been rationalized.

\section{Results and discussions}

Among the parks and squares of Uzhhorod, the Pidzamkovyi park is considered to be the oldest one. According to certain sources, the park started existing in the mid-XVI century to breed wild animals for king's hunting. In different times it was named Zvirynets', Horkyi's, Pidhradskyi and Pidzamkovyi. At the beginning of the 1870s, this territory was named Seczeni Park, in honour of the well-known civic-political figure (Kobal, Yosyp, 2008). 
In the times of Czecho-Slovakia in Pidzamkovyi park, the stadium "Spartak" was created (1901) for the sports club Rus'. At the same time, the city swimming pool appeared in the park. In August 1947 the children railway was opened (Kobal, Yosyp. 2008).

The main part of the greenery constituted the following species: Populus $\times$ canescens (Aiton) Sm., P. nigra L., P. alba L., Carpinus betulus L., Fagus sylvatica L., Qercus robur L., Pinus sylvestris L. Tilia cordata Mill. The first exotic plant, that was planted in this urban forest is Platanus occidentalis L. It is considered to have been planted in the XV c. by the proprietor of Uzhhorod castle Drugget. He came from Italy and probably, brought with him many popular in the south plants. Out of them, only this plane tree was preserved, it is considered to be above 500 years old. It is the oldest speciman among the Uzhhorod plantations. (Soima, A. D., 2011). Until today there have been preserved some age specimen of Fraxinus excelsior L., Tilia cordata, Populus $\times$ canescens, which are over 300 years old.

During the reconstruction (at the beginning of the XX centuries) the plantations were completed by the groups of Pinus sylvestris, P. nigra, J. F.Arnold, Robinia pseudoacacia L., Aesculus hippocastanum L., Populus pyramidalis Rozier., Morus nigra L., Philadelphus coronarius L., Deutzia scabra Thunb., Syringa vulgaris L. etc. (The Plant List, 2013).

As for today, Pidzamkovyi park is a monument of garden and park art of local significance. From the north-east of the park the sports complex "Spartacus" is situated, from the south - city swimming pool (aquapark) (Fig. 1). On the territory of the park, one can single out the following functional zones: of children's leisure, Uzhhorod children railway, parking, food service.

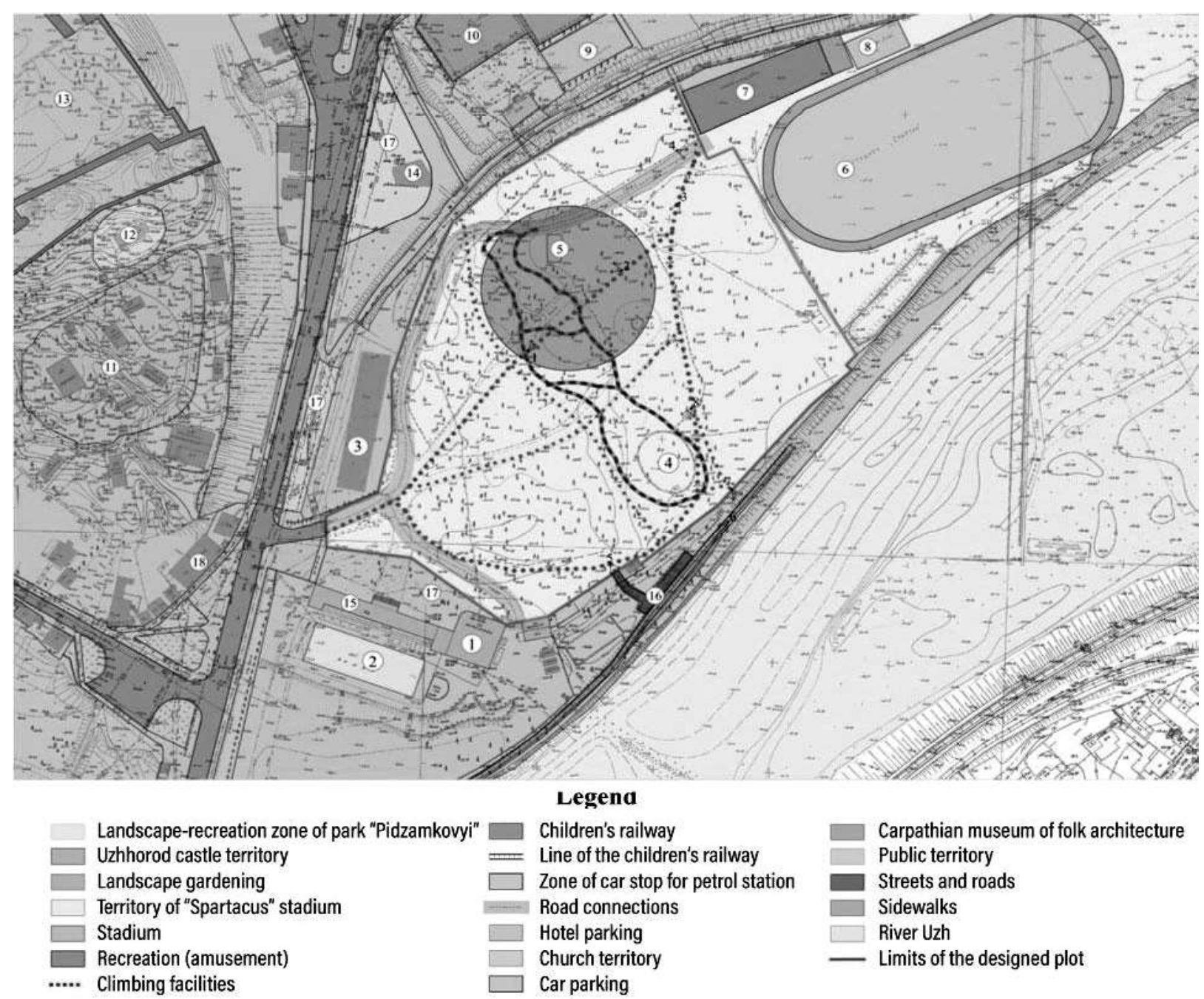

Fig. 1. Key plan of the Pidzamkovyi park (Authors: Mariutsa V., Denysenko M., Horovyuk O.) 
The park, park, having an area only of 4 hectares, has not withstood the load placed on it for a long time and does not meet the requirements of the Building code for such facilities. The climbing facilities on the trees destroy precious species and lead to the destruction of nature's monument in general. The existing here transit functional connections need proper organization and convenience. Further use of this park for cultural-mass events will lead to the loss of valuable plantations and ruining of the historical landscape of the city. That is why the issue of removing the functions of the culture and recreation park from it is now extremely acute. Instead of it, this territory can be used as a place for the local rest of the residents living around (Fig. 2, 3).

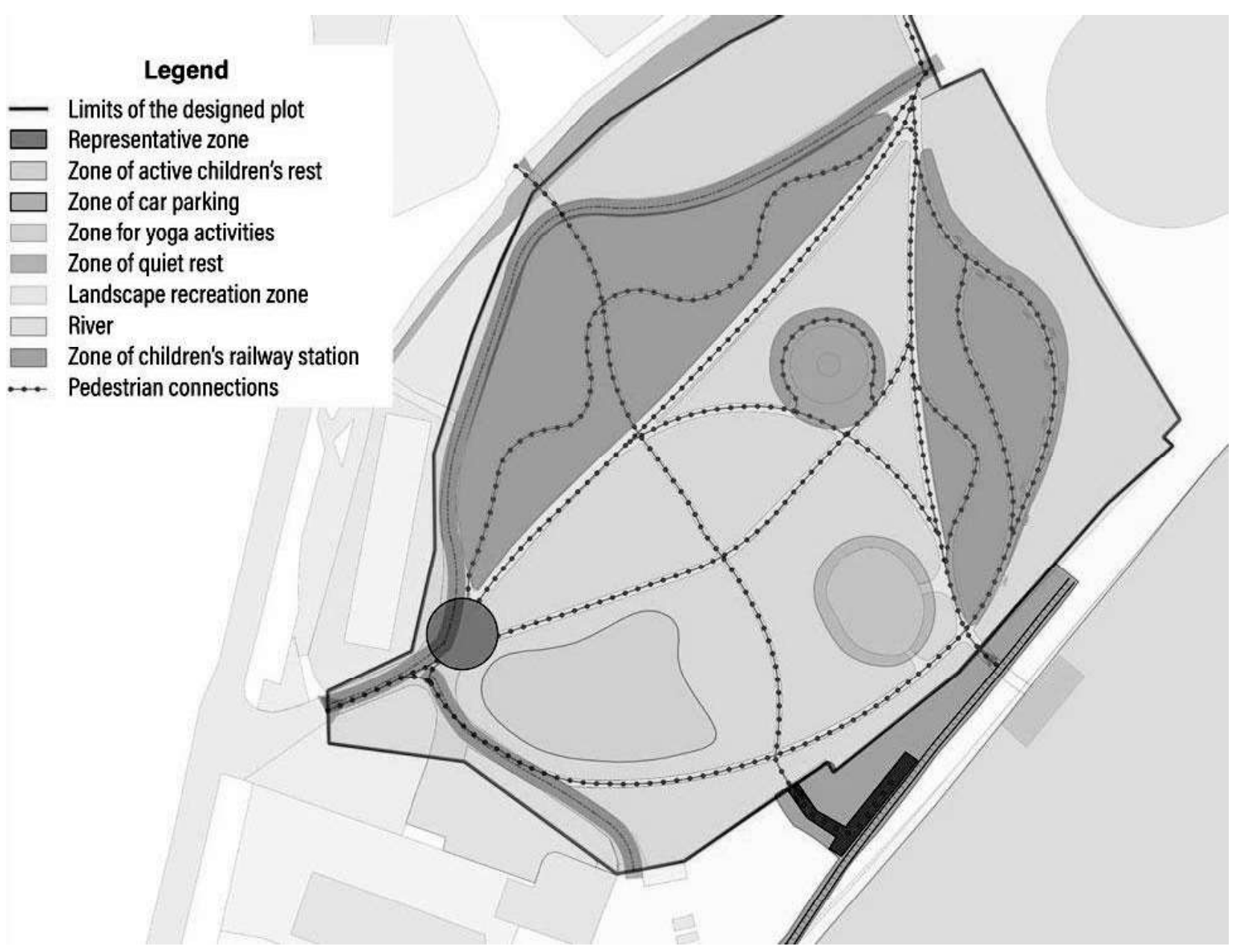

Fig. 2. Scheme of functional zoning (Authors: Mariutsa V., Denysenko M., Horovyuk O.)

When the city is already formed, it is quite difficult to define, the territory of which of the existing parks is the most suitable for the organization of such type of objects. If one considers the planning structure of Uzhhorod, the most favourable place for the organization of the general city park of culture and rest is Bozdoskyi park. The great territory of the park (over 50 hectares), its location in the central part of the city, combined with the landscape-recreation zone of the Uzh river gives us grounds to maintain that the given territory is the most favourable for fulfilling all the functional processes which should be encompassed by the general city park of culture and rest.

Bozdoskyi park was established in 1954 and divided into three main zones: zone of green plantations, zone of amusement rides and the zone of business activities. At present, there is functioning and is supported in the proper state only in the southern part of the park (Fig. 4). 


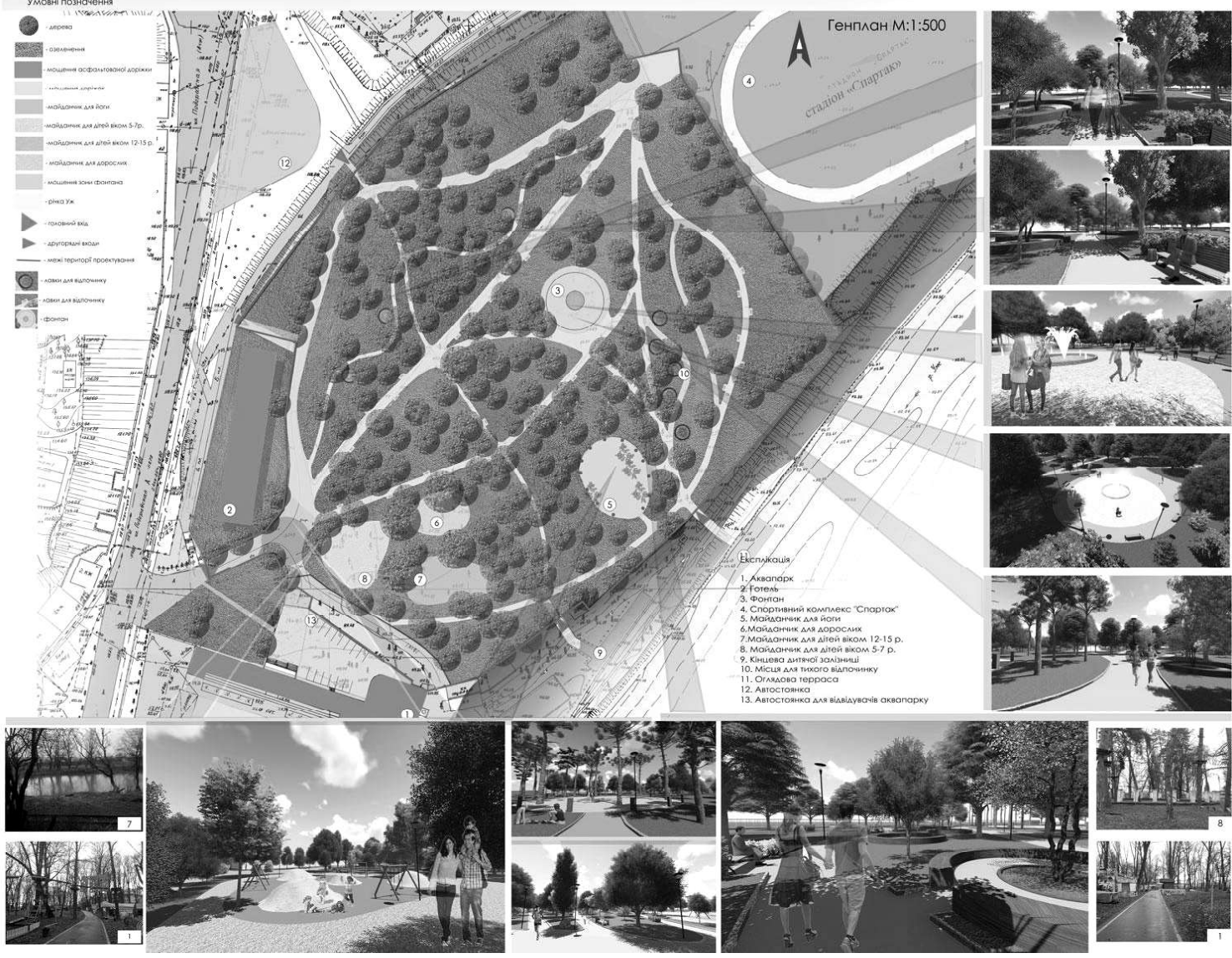

Fig. 3. Concept of development of Pidzamkovyi park (Authors: Mariutsa V., Denysenko M., Horovyuk O.)

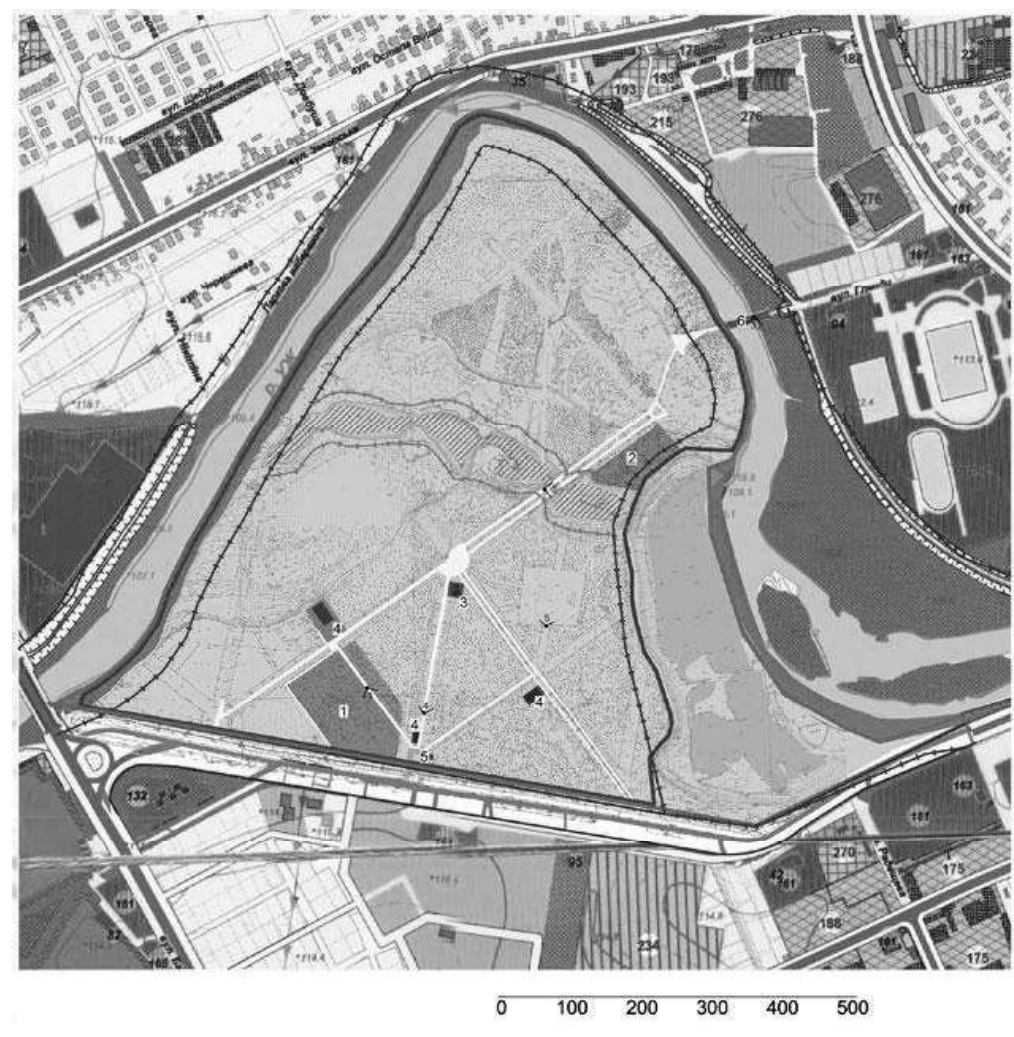

\section{Legend}

Limit of the designed territory
Limit of Bozdoskyi park
Riverside protection zones of the
ivers and bodies of water
Park landscaped territories
Red lines of streets
Territories of engineer protection
of the territory
Villa residential development
Blocks of flats
Snterprises and service establishments
Green plantations of general use
Green plantations of special purpose
Dachas, garden societies
Industrial enterprises
Special territores
Agricultural enterprises
Marsh territories
Rivers, lakes, ponds
Bain streets
Bridges, viaducts

Legend

1. Amusement rides

2. Car amusemnt rides

3. Sacral building

4. Places and objects of food service

5. Parking

6. Foot bridge

Fig. 4. Key plan of Bozdoskyi park (Authors: Rakochiy Ya., Rakochiy S.) 
A part of the park that adjoins the river Uzh is in a neglected state and needs arrangement. It is necessary to state that the territory itself is very attractive both from the aesthetic point of view, as well as from the urban development one. From the territory of the park, one can see beautiful landscapes over the river and the bank opposite it. From the territory of the park, there are beautiful views over the river and the opposite bank. Such places are distinct by greater attractivity and draw the population to themselves. The not less important factor is the accessibility and wonderful location in the city. The existing bridge provides accessibility from both parts of the city.

Today the necessity has arisen to renew the concept of Bozdoskyi park development and bring it to modern demands. In the north-eastern part of the park, it is expedient to place a sports area, which will be a logical continuation of the sports function of "Avant-garde" stadium, that is situated on the opposite side of the river (Fig. 5). Besides sports zones, it is necessary also to foresee territories for cultural - mass events, for children's plays, for walks, for modern attractions and a network of walking paths that will unite the main parts of the park. In general, the functional-planning structure should be oriented at the correspondence to the demands of the park of culture and rest, and the location to be harmoniously combined with the zone for rest on the city embankment (Fig. 6).

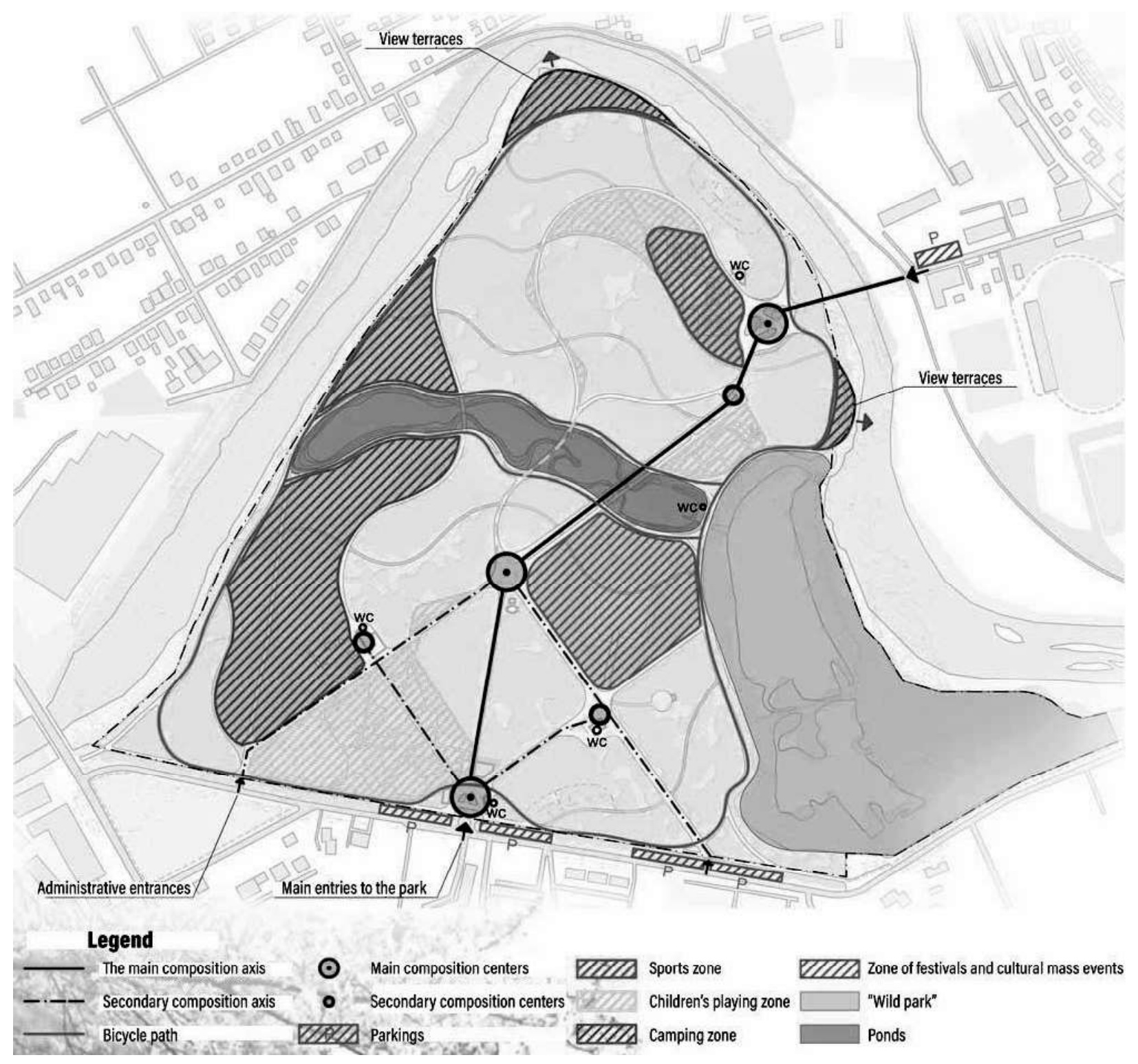

Fig. 5. Scheme of functional zoning of Bozdoskyi park (Authors: Rakochiy Ya., Rakochiy S.) 


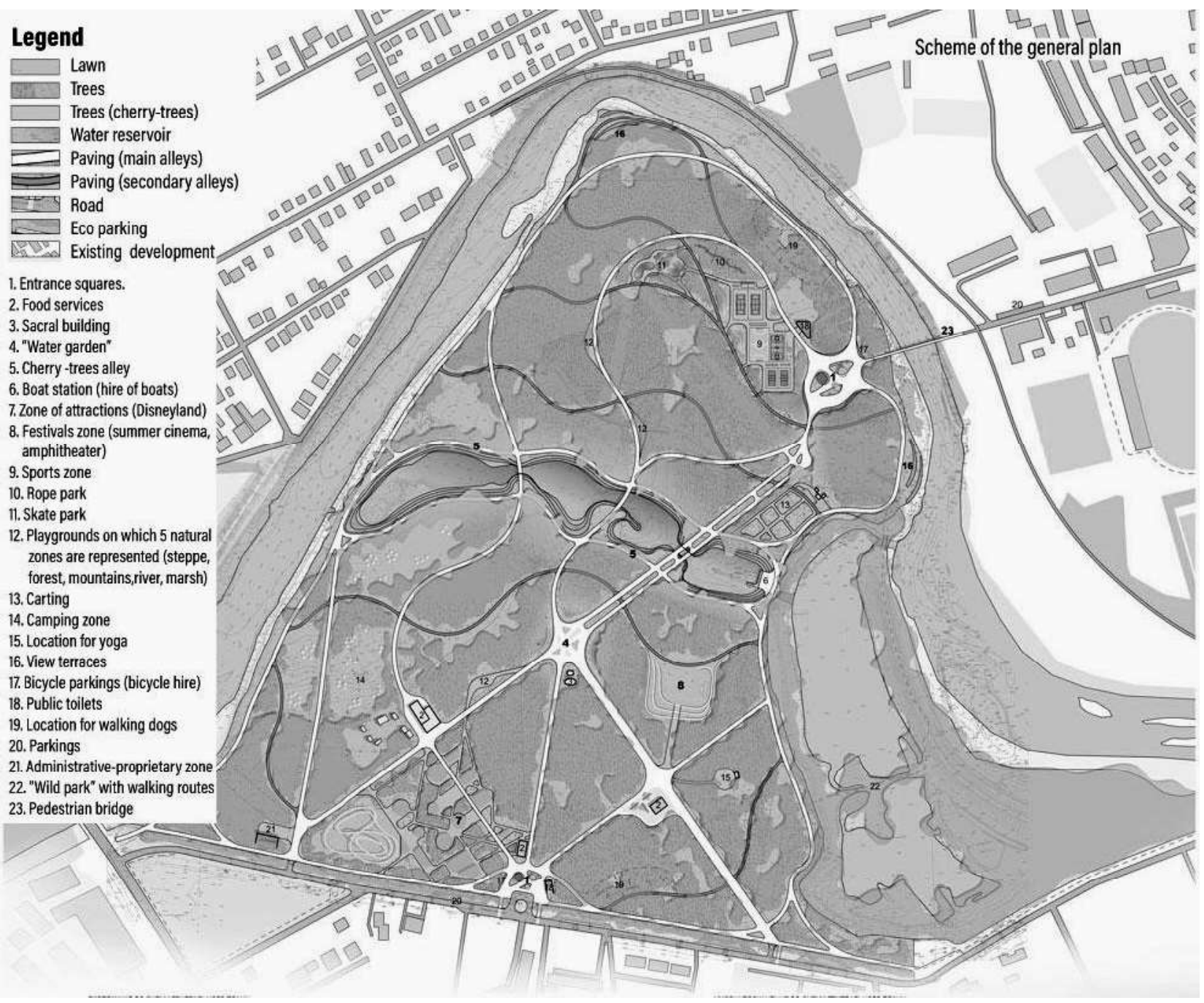

Fig. 6. Scheme of the general plan of Bozdoskyi park (Authors: Rakochiy Ya., Rakochiy S.)

\section{Conclusions}

As a result of the researches held it was ascertained that the Pidzamkovyi park cannot fulfil the function of the general city park of culture due to the following reasons:

- Pidzamkovyi park contains several valuable species of trees (ancient plane-tree of Druggets, ancient lime trees and ash-trees) and is a monument of garden and park art of local significance. On the territory of the park, the monument of garden and park art, any activity is prohibited that is not connected with fulfilling the tasks given to it and endangers its preservation;

- the park area does not correspond to the demands concerning the organization of culture parks;

- impossibility to provide the necessary functional-planning connections with the settlement territory of the city.

According to the results of the research of the landscape-spatial structure of Pidzamkovyi park, it was suggested to put it to reconstruction and to form in it the following zones: representative one, of children's rest, landscape-recreative, of quiet rest, of children's railway and parking. It is suggested to hold monitoring and preservation of green plantations, measures on optimization of anthropogenic loads.

Analysing the existing parks of Uzhhorod it was defined that for the function of the general city park of culture and rest the most corresponding is Bozdoskyi park which contains all the necessary components 
for organizing the spending of leisure of the city population: accessibility, sufficient area and recreational resources. There was fulfilled the proposal of the general plan of the park for the public discussion.

\title{
References
}

Jan Maciej Chmielewski. 2010. Teoria urbanistyki w projektowaniu i planowaniu miast. Vyd. 2-e. Warszawa. $416 \mathrm{s.}$

The Plant List: Version 1.1 (2013). [online]. Available at: $<$ http://www.theplantlist.org $>$ Name from the screen. [Accessed date: 14.09 .2020$]$.

But N. K. 2013. Pryntsypy arkhitekturno-planuvalnoi orhanizatsii naberezhnykh Uzhhoroda. Naukovyi visnyk NLTU Ukrainy : zb. naukovo-tekhnichnykh prats. Lviv : RVV NLTU Ukrainy. Vyp. 23.9. S. 148-153.

DBN B.2.2-12:2018. Planuvannia i zabudova terytorii. - Kyiv : Minrehion Ukrainy. $179 \mathrm{~s}$.

Zakon Ukrainy pro PZF (H. 11. St. 38. Osnovni vymohy shchodo rezhymu parkiv-pamiatok sadovo-parkovoho mystetstva) [online]. Available at: <https://zakon.rada.gov.ua/cgi-bin/laws/main.cgi?page=2\&nreg=2456-12\#Text> [Accessed date: 14.09.2020].

Kobal, Yosyp. 2008. Uzhhorod vidomyi i nevidomyi. Vyd. 2-e, vypr. Lviv : Svit. 196 s.

Mistobudivne proektuvannia. 2016. Ch. 1: Misto yak obiekt proektuvannia: navchalnyi posibnyk. H. P. Petryshyn, B. S. Posatskyi, Yu. I. Kryvoruchko ta in.; za red.: H. P. Petryshyn, B. S. Posatskoho, Yu. V. Idak. Lviv : Vydavnytstvo Lvivskoi politekhniky. $328 \mathrm{c}$.

Mistobuduvannia: Dovidnyk proektuvalnyka. 2001; za red. Panchenko T. F. - K. : Ukrarkhbudinform. $192 \mathrm{~s}$.

Systema monitorynhu dovkillia Zakarpatskoi oblasti [online]. Available at: <http://ecozakarpat.net.ua/parks/park-pamiatka-sadovo-parkovogho-mistietstva-mistsievogho-znachiennia-pidzamkovii> [Accessed date: 14.09.2020].

Soima, A. D. 2011. Ekzoty dendroflory m. Uzhhorod, Naukovyi visnyk Uzhhorodskoho universytetu. Seriia Biolohiia, Vyp. 30. Uzhhorod. S. 32-37.

Fodor S. S. 1951. K voprosu ob yzuchenyy эkzotov Zakarpattia. Naukovi zapysky. T. IV. biolohichna seriia. Uzhhorod : Oblasne knyzhkovo-zhurnalne vydavnytstvo. S. 68-86.

Fodor S. S. 1957. Ystoryia y puty yntroduktsyy drevesnыkh y kustarnıkh nasazhdenyi v Zakarpate. Nauchnue zapysky, botanyka. T. XXIII. Uzhhorod. S. 167-182.

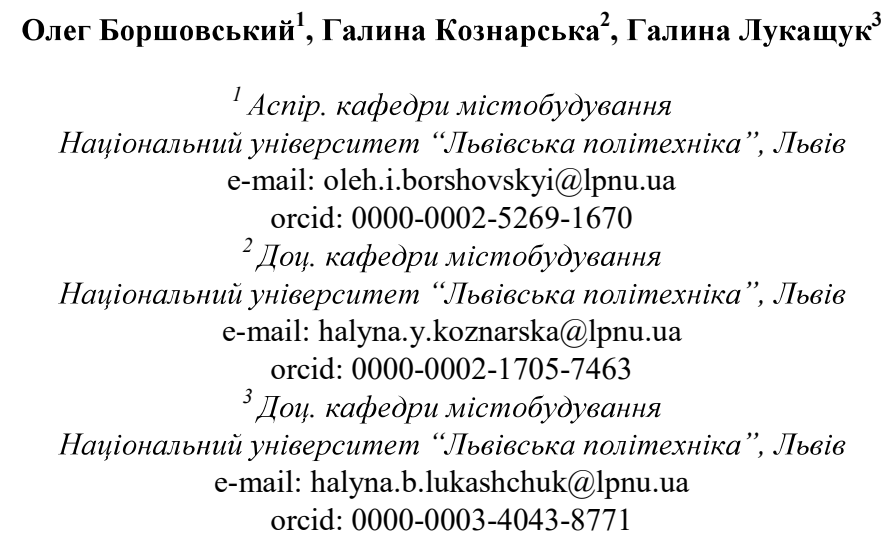

\section{ОРГАНІЗАЦІЯ ЗАГАЛЬНОМІСЬКОГО ПАРКУ КУЛЬТУРИ ТА ВІДПОЧИНКУ У м. УЖГОРОДІ}

\begin{abstract}
Анотація. Досліджено парки Ужгорода, аргументовано доцільність перенесення парку культури та відпочинку 3 Підзамкового до Боздоського. Підзамковий парк, площею всього 4 га, вже давно не витримує навантаження, яке на нього покладене та не відповідас вимогам ДБН, шодо подібних об'єктів. Подальше використання иього парку для культурномасових заходів призведе до втрати цінних насаджень та руйнування історичного ландшафту міста. Тому, питання винесення з нього функиій парку культури та відпочинку на даний час постало надзвичайно гостро. Натомість, ця територія може бути використана як місие локального відпочинку навколишніх мешканиів. Для функиії загальноміського парку культури та відпочинку запропоновано Боздоський парк, який містить всі необхідні компоненти для організації проведення дозвілля населення міста: доступність, достатню площу та рекреаційні ресурси.
\end{abstract}

Ключові слова: парк культури, рекреація, ландшафтно-рекреачійна зона, пам'ятка садово-паркового мистеитва. 